\title{
PENGARUH PENGGUNAAN KARBON AKTIF AMPAS TEBU TERHADAP PENURUNAN SALINITAS PADA SUMUR GALI DI RT 003 RW 006 KELURAHAN TANJUNG UNGGAT KOTA TANJUNGPINANG TAHUN 2017
}

\author{
Noviana $^{1}$, Hevi Horiza², Gina Dwi Nur Kusuma ${ }^{3}$ \\ Jurusan Kesehatan Lingkungan Poltekkes Kemenkes Tanjungpinang \\ e-mail: noviana26cintasz@gmail.com, hevi220987@gmail.com \\ DOI : 10.24036/eksakta/vol19-iss01/97
}

\begin{abstract}
Salinity levels of one dug well water in RT 003 RW 06 Kelurahan Tanjung Unggat Tanjungpinang exceeded the quality standard that is $2 \%$ so need do the processing of dug well water is one of them using activated carbon bagasse. The purpose of this study was to determine the rate reduction salinity dug wells in RT 003 $R W 06$ Kelurahan Tanjung Unggat Tanjungpinang after being treated with activated carbon bagasse. This research was experimental (experimental research), with the design of One Group Pretest Posttest results measurement performed before and after treatment. Data were analyzed using univariate and bivariate, then tested with One Way Anova statistic. The results showed decreased levels of salinity using bagasse activated carbon with dose variations of 2 grams and a contact time of 30, 60, 90, 120 and 150 minutes with percentages respectively $11.5 \%, 26.5 \%, 61.5 \%, 76.5 \%$ and $91.5 \%$. From the research results can be concluded that there is the effect of adding activated carbon bagasse in reducing the salinity of the water wells in RT $003 R W 06$ Kelurahan Tanjung Unggat Tanjungpinang 2017. Suggestions for further research to combine with aeration and filtration media to obtain results better.
\end{abstract}

Keywords: Activated Carbon, Cane Dregs, Salinity

\section{PENDAHULUAN}

Salah satu komponen lingkungan yang mempunyai peranan cukup besar dalam kehidupan adalah air. Bagi manusia, air berperan dalam kegiatan pertanian, industri dan pemenuhan kebutuhan rumah tangga. Air yang digunakan harus memenuhi syarat dari segi kualitas dan kuantitasnya. Kualitas air dapat ditinjau dari segi fisika, kimia dan biologi. Bahkan, di daerah-daerah tertentu air yang tersedia tidak memenuhi syarat kesehatan sehingga diperlukan upaya perbaikan secara sederhana maupun modern (Kusnaedi, 2010).

Kota Tanjungpinang merupakan salah satu daerah ketersediaan air yang memenuhi syarat kesehatan sangat terbatas. Untuk mengatasi masalah tersebut kota Tanjungpinang telah melakukan pengolahan air melalui PDAM namun tidak semua wilayah di kota Tanjungpinang yang dapat mengaksesnya. Pada tahun 2014 rata-rata rumah tangga menggunakan air kemasan atau air isi ulang sebagai sumber air minum sebesar $70,29 \%$, sedangkan yang menggunakan air sumur sebanyak 17,47\%. Berdasarkan data Statistik Kota Tanjungpinang tahun 2015 rumah tangga yang telah menggunakan air PDAM mengalami penurunan menjadi $6,05 \%$.

Akses air bersih menurut sarana yang digunakan oleh Kelurahan yang 
berada di Wilayah Kerja Puskesmas Tanjungpinang berdasarkan data Dinas Kesehatan Kota Tanjungpinang tahun 2016, untuk persentase tertinggi yaitu pada air sumur gali dan air PDAM masing-masing sebesar $19 \%$ dan $8 \%$, sedangkan untuk persentase terendah yaitu sumber air bersih yang berasal dari sumber lainnya sebesar $0,4 \%$. Air sumur yang dimanfaatkan oleh masyarakat pada umumnya tidak memenuhi syarat kesehatan, karena airnya yang kuning, keruh, bau besi, berlapisan minyak, memiliki rasa asin, dan pahit. Rasa asin dan pahit ini disebabkan karena tingginya angka salinitas dari air tersebut. Sumursumur yang memiliki angka salinitas tinggi pada umumnya adalah daerah yang berada di pesisir pantai atau daerah sekitar rawa.

Secara kuantitas, daerah pesisir umumnya memiliki air yang melimpah, tetapi sering mengalami kesulitan karena berkaitan dengan kelangkaan air tawar yang dapat dimanfaatkan sebagai air bersih. Pengaruh air laut terhadap air sumur sangat kuat di wilayah pesisir dan mempengaruhi kualitas air sumur secara umum. Secara kimia, besarnya pengaruh air laut tercermin pada tingginya salinitas (Lestari, 2014).

Salah satu daerah di Kota Tanjungpinang yang memiliki air dengan angka salinitas tinggi atau payau adalah kelurahan Tanjung Unggat. Berdasarkan hasil observasi sebelumnya yang dilakukan di Kelurahan Tanjung Unggat Kota Tanjungpinang, masyarakatnya bertempat tinggal di pesisir-pesisir pantai, sangat memungkinkan untuk terjadinya instrusi air laut ke air sumur mereka, hal ini menyebabkan kondisi air mereka menjadi payau sehingga dari hasil pengukuran terhadap angka salinitas di sumur gali tersebut diperoleh hasil $2 \%$.

Air yang memiliki salinitas terlalu tinggi dapat mendatangkan kerugian apabila sering digunakan untuk kegiatan sehari-hari, misalnya berbahaya untuk kesehatan apabila digunakan sebagai air minum, menyebabkan kegagalan panen pada pertanian, korosi pada peralatan dan bangunan yang terbuat dari unsur logam, untuk air bersih kadar salinitas $<0,5 \%$ dan air minum maksimal $0,2 \%$ (Kurniawan, 2014).

Kondisi ini perlu mendapat perhatian dan penanganan yang khusus agar diperoleh air dengan kualitas yang memenuhi standart, kualitas sanitasi, baku mutu lingkungan serta mencegah terjadinya gangguan kesehatan pada penggunaannya. Salah satu cara untuk mengatasi masalah tingginya angka salinitas adalah dengan teknik adsorbsi menggunakan karbon aktif.

Karbon aktif adalah material yang berbentuk butiran atau bubuk yang berasal dari material yang mengandung karbon. Bahan yang dapat dibuat menjadi arang aktif adalah tulang, kayu lunak, sekam, bonggol jagung, tempurung kelapa, sabut kelapa, ampas penggilingan tebu, ampas pembuatan kertas, serbuk gergaji, kayu keras dan batu bara. Karbon aktif biasanya digunakan sebagai katalis, penghilangan bau, penyerap warna, zat purifikasi dan sebagainya (Adinata, 2013).

Karbon aktif yang sering digunakan adalah karbon aktif dari tempurung kelapa, bahan lain yang sering digunakan sebagai karbon aktif adalah ampas tebu. Seiring berjalannya waktu, ampas tebu mulai jarang dimanfaatkan sehingga dianggap sebagai limbah yang tidak berguna dan menimbulkan pencemaran. Perkembangan Ilmu dan Teknologi, ampas tebu dapat dimanfaatkan menjadi karbon aktif. Serat ampas tebu mengandung karbon aktif murni $80 \%$, daya serap terhadap larutan $12 \%$ (Asbahani, 2013).

Menurut penelitian yang dilaksanakan Sutiyani (2015) arang aktif yang terbuat dari ampas tebu dapat dijadikan sebagai adsorben yang efektif dalam menurunkan kadar zat pewarna 
jeans dalam air limbah, karena belum adanya penelitian yang memanfaatkan karbon aktif dari ampas tebu dalam menurunkan angka salinitas air sumur gali, maka peneliti tertarik untuk menurunkan angka salinitas menggunakan bahan tersebut.

\section{METODE}

Penelitian ini merupakan penelitian eksperimen dengan Desain Penelitian ini adalah pra-eksperimen dengan rancangan One Group Pretest Posttest. Rancangan penelitian ini tidak ada kelompok pembanding (control), dan dilakukan observasi pertama pretest $(\mathrm{O} 1)$ yaitu pengukuran kadar salinitas pada air sumur gali, kemudian diberi perlakuan atau intervensi (x) pada air sumur tersebut dan dilakukan posttest (O2) yang bertujuan untuk mengetahui adanya pengaruh kadar salinitas setelah diberi perlakuan (eksperimen). Penelitian ini dilakukan di Laboratorium Jurusan Kesehatan Lingkungan Poltekkes Kemenkes Tanjungpinang dari bulan Januari sampai dengan Juni 2017.

Alat-alat yang digunakan adalah Jerigen 2 liter, Ember timba, Corong, Ember / wadah, Ayakan / jaring ukuran 200 mesh, Drum besi / tong, Tungku, Oven, pisau, Korek api, Beaker glass, Timbangan Analitik, Magnetik Stirer, Saringan, Corong, Stopwacth, Refraktometer, Pipet Tetes. Bahan yang digunakan adalah kertas label, ampas tebu, bahan bakar minyak, aquades, $\mathrm{HCl}$, $\mathrm{NaOH}$ dan Air Sumur

1. Pengambilan Sampel Air Sumur

Siapkan alat pengambil contoh sesuai dengan jenis air yang akan diuji. Bilas alat dengan contoh yang akan diambil sebanyak 3 kali. Ambil contoh sesuai dengan peruntukan analisis. Masukkan kedalam wadah yang sesuai peruntukan analisis. Lakukan segera pengukuran $\mathrm{PH}$ dan suhu. Hasil pengujian parameter lapangan dicatat dalam buku. Berikan label yang berisikan (tujuan, sarana, lokasi atau tempat, waktu, tanggal, petugas, dan paraf petugas).

2. Pembuatan Karbon Aktif

Sebelum melakukan karbonisasi, ampas tebu tersebut dikeringkan selama 5 hari Kemudian lakukan proses karbonisasi sebagai berikut: Siapkan alat dan bahan. Masukkan ampas tebu disusun secara tegak di dalam drum yang diberikan cerobong asap. Nyalakan api dan biarkan beberapa saat hingga proses karbonisasi keseluruhan ampas tebu merata sempurna hingga asap yang keluar berwarna putih. Karbon aktif ampas tebu diayak menggunakan ayakan 100 mesh. Selanjutnya diaktivasi, pada penelitian ini sesuai dengan penelitian Johan (2015), proses pengaktivasian arang menggunakan aktivasi secara kimia yang menggunakan larutan Asam Klorida $(\mathrm{HCl})$ dilanjutkan dengan menggunakan larutan Natrium Hidroksoda $(\mathrm{NaOH})$.

3. Aktivasi dengan asam $(\mathrm{HCl})$

Aktivasi dengan asam dilakukan dengan mencampurkan karbon dengan asam klorida $(\mathrm{HCl}) \quad 0,5 \mathrm{M}$ pada perbandingan karbon : asam yaitu 1:3 (100 gr karbon dalam 300 $\mathrm{ml} \mathrm{HCl} 0,5 \mathrm{M}$ ) campurkan kemudian diaduk selama 1 jam pada suhu $70^{\circ} \mathrm{C}$ dan didiamkan semalam pada suhu ruang kemudian cuci karbon menggunakan aquades hingga $\mathrm{pH}$ netral, karbon di keringkan dalam oven pada suhu $110^{\circ} \mathrm{C}$ selama 4 jam.

\section{Aktivasi dengan basa $(\mathrm{NaOH})$}

Aktivasi dengan basa dilakukan dengan mencampurkan karbon dengan natrium hidroksida $(\mathrm{NaOH})$ 0,5 M pada perbandingan karbon: basa yaitu 1:3 (100 gr karbon dalam $300 \mathrm{ml} \mathrm{NaOH}$ 0,5 M) campurkan 
kemudian diaduk selama 1 jam pada suhu $70^{\circ} \mathrm{C}$ didiamkan semalam pada suhu ruang kemudian cuci arang menggunakan aquades hingga $\mathrm{pH}$ netral, karbon dikeringkan dalam oven pada suhu $110^{\circ} \mathrm{C}$ selama 4 jam.

\section{Perlakuan terhadap sampel}

Dalam menentukan waktu kontak optimum dengan dosis karbon 2 gr, dalam penelitian ini mengacu pada penelitian Asbahani (2013) yaitu sebagai berikut : Siapkan alat dan bahan. Timbang karbon aktif ampas tebu sebanyak 2 gr. Sampel dimasukkan ke dalam beaker glass masing-masing sebanyak $100 \mathrm{ml}$. Masukkan karbon aktif ampas tebu yang telah ditimbang ke dalam masing-masing beaker glass yang berisi air sampel. Aduk menggunakan stirer dengan kecepatan $100 \mathrm{rpm}$ dalam waktu 30 menit. Endapkan larutan dengan waktu kontak 30, 60, 90, 120, dan 150 menit, kemudian saring filtrat ampas tebu. Kandungan salinitas dalam sampel di ukur dengan Refraktometer dan dilakukan 2 kali pengulangan.

\section{HASIL DAN PEMBAHASAN}

\section{Hasil}

Angka salinitas sebelum diberi perlakuan yaitu $2 \%$, setelah diberi perlakuan dengan 2 gram karbon aktif ampas tebu dan variasi waktu kontak karbon aktif ampas tebu, pada waktu kontak 150 menit diperoleh rata-rata penurunan angka salinitas sebesar 1,83 $\mathrm{O} \%$ atau terjadi penurunan sebesar $91,5 \%$, dan terjadi penurunan secara signifikan angka salinitas dalam air hingga mencapai konsentrasi $0,2 \%$ oo, angka salinitas dalam sampel air sumur gali setelah perlakuan dengan karbon aktif ampas tebu memenuhi persyaratan berdasarkan permenkes no 416 tahun 1990 yaitu nilai ambang batas kadar salinitas dalam air bersih 0,5\% \% (Tabel $1)$.

Tabel 1. Hasil Pengukuran Penentuan Waktu Kontak Optimum Karbon Aktif Ampas Tebu

\begin{tabular}{|c|c|c|c|}
\hline $\begin{array}{c}\text { Waktu } \\
\text { Kontak } \\
(\text { Menit })\end{array}$ & $\begin{array}{c}\text { Sebelum } \\
\text { Perlakuan } \\
(\%)\end{array}$ & $\begin{array}{c}\text { Setelah } \\
\text { Perlakuan } \\
(\%)\end{array}$ & $\begin{array}{c}\text { Persen } \\
\text { Penurunan } \\
(\%)\end{array}$ \\
\hline 30 & 2 & 1,77 & 11,6 \\
\hline 60 & 2 & 1,47 & 26,5 \\
\hline 90 & 2 & 0,77 & 61,5 \\
\hline 120 & 2 & 0,47 & 76,5 \\
\hline 150 & 2 & 0,17 & 91,5 \\
\hline \multicolumn{2}{|r|}{ Rata-rata Penurunan } & $\mathbf{1 , 0 7}$ & $\mathbf{5 4}$ \\
\hline
\end{tabular}

Analisis bivariat dalam penelitian ini bertujuan untuk mengetahui pengaruh pemanfaatan karbon aktif ampas tebu dalam menurunkan angka salinitas air sumur gali di RT 003 RW 06 Kelurahan Tanjung Unggat Kota Tanjungpinang. Berdasarkan hasil uji normalitas menggunakan uji One Sample Kolmogorov Smirnov diperoleh hasil nilai $\mathrm{p}=0,333$ untuk data dengan variasi waktu kontak 30, 60, 90, 120 dan 150 menit. Hal ini menunjukan nilai $\mathrm{p}>0,05$ sehingga data penelitian ini berdistribusi normal. Maka analisis data menggunakan uji One Way Anova untuk melihat pengaruh pemanfaatan ampas tebu dalam menurunkan angka salinitas air sumur gali di RT 003 RW 06 Kelurahan Tanjung Unggat Kota Tanjungpinang. Berdasarkan hasil uji dengan menggunakan perangkat komputer diperoleh hasil nilai $\mathrm{p}=0,000$, hal ini menunjukkan bahwa Ha diterima yaitu ada pengaruh penggunaan karbon aktif ampas tebu terhadap penurunan angka salinitas sumur gali di RT 003 RW 06 Kelurahan Tanjung Unggat Kota Tanjungpinang.

\section{Pembahasan}

Berdasarkan penelitian yang telah dilakukan terjadi penurunan terhadap angka salinitas sampel air sumur gali setelah diberi perlakuan menggunakan karbon aktif ampas tebu terjadi penurunan 
rata-rata sebesar 1,07\%. Hal ini sejalan dengan penelitian Dahlan (2013) yang melakukan pengolahan air payau digunakan rangkaian alat yang terdiri atas 3 buah media dengan kadar penyaringan yang berbeda-beda. Air payau di lewatkan melalui media 1 yaitu batu kuarsa (250 gr), partikel-partikel pengotor dengan ukuran yang maksimal akan di tangkap sehingga mengurangi kadar pengotor yang akan masuk ke media ke 2 , untuk media kedua tersedia karbon aktif (500 gr). Keberadaan karbon aktif pada filter untuk proses adsorpsi sehingga terjadi proses penyerapan kadar garam pada air tersebut. Akar mangrove yang diproses menjadi karbon aktif dapat digunakan sebagai adsorben untuk proses desalinasi air laut menjadi air tawar melalui proses adsorpsi. Penurunan kadar klorida terbesar senilai $15,3 \%$ menggunakan karbon aktif akar mangrove dengan aktivasi $\mathrm{H}_{2} \mathrm{SO}_{4}$ (Caroline, 2017).

Karbon aktif yang memiliki pori-pori lebih kecil akan menangkap pengotor yang terbawa dari media. Daya serap karbon aktif sangat besar, yaitu 25-1000 $\%$ terhadap berat karbon aktif. Dalam satu gram karbon aktif, pada umumnya memiliki luas permukaan seluas 500-1500 $\mathrm{m} 2$, sehingga sangat efektif dalam menangkap partikel-partikel yang sangat halus berukuran 0,01 - 0,0000001 mm. Karbon aktif bersifat sangat aktif dan akan menyerap apa saja yang kontak dengan karbon tersebut. Pengolahan air payau dengan menggunakan 3 media yaitu batu kuarsa, karbon aktif dan membran keramik bertujuan untuk menghasilkan air payau yang lebih jernih dengan kadar garam yang lebih sedikit.

Waktu kontak terbaik dalam menurunkan konsentrasi kadar garam pada air sumur gali dengan karbon aktif dari ampas tebu dengan aktivator $\mathrm{HCl}$ dan $\mathrm{NaOH}$ konsentrasi $0,5 \mathrm{M}$ adalah 150 menit dan dosis 2 gram.

Semakin lama waktu kontak karbon aktif terhadap sampel maka semakin besar daya serapnya terhadap angka salinitas dalam air, hal ini sejalan dengan penelitian Asbahani (2013) menyatakan bahwa kapasitas adsorbsi berbanding lurus dengan waktu sampai pada titik tertentu, kemudian mengalami penurunan setelah melewati titik tersebut dan berdasarkan penelitian Manocha (2003) adsorbsi merupakan suatu fenomena yang berkaitan erat dengan permukaan di mana terlibat interaksi antara molekul-molekul cairan atau gas dengan molekul padatan. Interaksi ini terjadi karena adanya gaya tarik atom atau molekul yang menutupi permukaan tersebut. Kapasitas adsorbsi dari karbon aktif tergantung pada jenis pori dan jumlah permukaan yang mungkin dapat digunakan untuk mengadsorbsi. Sehingga disimpulkan waktu kontak berpengaruh terhadap daya serap karbon aktif ampas tebu terhadap angka salinitas dalam air. Hal ini dapat dilihat pada tabel 1. Penelitian ini membuktikan bahwa karbon aktif ampas tebu memiliki daya serap yang cukup tinggi dan dapat dimanfaatkan dalam memperbaiki kualitas air bersih khususnya menurunkan angka salinitas atau kandungan garam pada air.

\section{KESIMPULAN}

Kandungan kadar garam / salinitas pada air sumur gali di RT 003 RW 06 Kelurahan Tanjung Unggat Kota Tanjungpinang sebelum diberi perlakuan adalah sebesar $2 \%$ dan setelah menggunakan karbon aktif ampas tebu terjadi penurunan rata-rata sebesar 1,07 $\%$. Waktu kontak optimum karbon aktif ampas tebu teraktivasi dalam menurunkan angka salinitas adalah pada waktu kontak 150 menit yang mengalami penurunan sebesar $1,83 \%$ atau persentase penurunan sebesar $91,5 \%$.

\section{DAFTAR PUSTAKA}

Adinata,M.R. 2013. Pemanfaatan Limbah Kulit Pisang, Jurnal Jurusan Teknik Kimia. 
Asbahani 2013. Pemanfaatan Limbah Ampas Tebu Sebagai Karbon Aktif Untuk Menurunkan Kadar Besi pada Air Sumur. Alumnus Prodi Teknik Arsitektur. Jurusan Teknik Sipil Fakultas Teknik. Universitas Tanjungpura, Vol 13.

Dahlan, H. 2013. Prototipe Alat Penyaringan Air Payau (sungai Sugihan) menjadi Sumber Air Bersih Menggunakan Tabung Filter Bagi Masyarakat Pangkalan Sakti, Kecamatan Air Sugihan Kabupaten Organ Komering Ilir Sumsel. Teknik Kimia.

Kurniawan. A, Bambang R, L, D. 2014. Pengaruh Zeolit Alam Termodiikasi Hdtma Terhadap Penurunan Salinitas Air Payau.
Sumber

Daya

Alam

dan Lingkungan.

Kusnaedi. 2010. Mengolah Air Kotor Untuk Air Minum. Jakarta: Penebar Swadaya.

Lestari, A.D., \& Sambodho, K. 2014. Pengaruh Kenaikan Permukaan Air Laut pada Intrusi Air Laut Di Akuifer Pantai.

Manocha, S.M. 2003. Porous Carbons, 28 April 2017.

Permenkes No. 416/Menkes/Per/IX/1990. Tentang Syarat-syarat dan Pengawasan Kualitas Air.

Sutiyani, \& Tama, A. 2015. Untuk Pengolahan Air Limbah Pewarnaan Jeans. 